\title{
International Students' Academic Achievement and Progress in Turkish Higher Education Context: Students' and Academics' Views
}

\author{
Ceyhun Yükselir \\ Department of English Language and Literature, Faculty of Arts and Sciences, Osmaniye Korkut Ata University, \\ 80000, Osmaniye, Turkey
}

Copyright $\mathrm{C} 2018$ by authors, all rights reserved. Authors agree that this article remains permanently open access under the terms of the Creative Commons Attribution License 4.0 International License

\begin{abstract}
This study aims to express the international students' and academics' views about the conditions that affect academic achievement and progress of international students at a Turkish university from a qualitative research paradigm. The participants were 15 international students (10 males and 5 females) and 8 academics from different disciplines in the target university. Open-ended questions and classroom observations were employed to collect data. Also, second-wave interviews were conducted with the participants in order to have a deeper understanding the conditions influencing their academic achievement and progress. The collected data were analyzed by conducting thematic analysis. The findings concerning international students' views indicated that one of the most important factors that affect their academic achievement and progress is related to the proper use of the Turkish language proficiency, especially in writing. In parallel with students' views, the academics also stated that they are not satisfied with the whole progress of the international students in the classroom because they sometimes have communication problems within the course. All in all, the findings suggest that the model of instruction for international students in higher education should be grounded well and organized
\end{abstract}

systematically. Implications are discussed for fostering the standards of teaching international students in higher education.

Keywords International Students, Turkish Higher Education, Academic Achievement and Progress, Views

\section{Introduction}

In this rapidly changing and evolving world, a steady flux of international students to Turkish higher education has been increasing. The number of international students studying in Turkish universities is 103.727 [22]. This number seems to have doubled when checking the current number of international students registered in the Ministry of National Education, which is 232.714. As Figure 1 [22] shows, international students in Turkey are mainly from Syria and Azerbaijan. Considering western Turkey, there are many international students from different countries especially in the metropolitan cities such as Istanbul, Ankara and İzmir. However, this is not the case in the eastern part of Turkey and the small cities in the country.

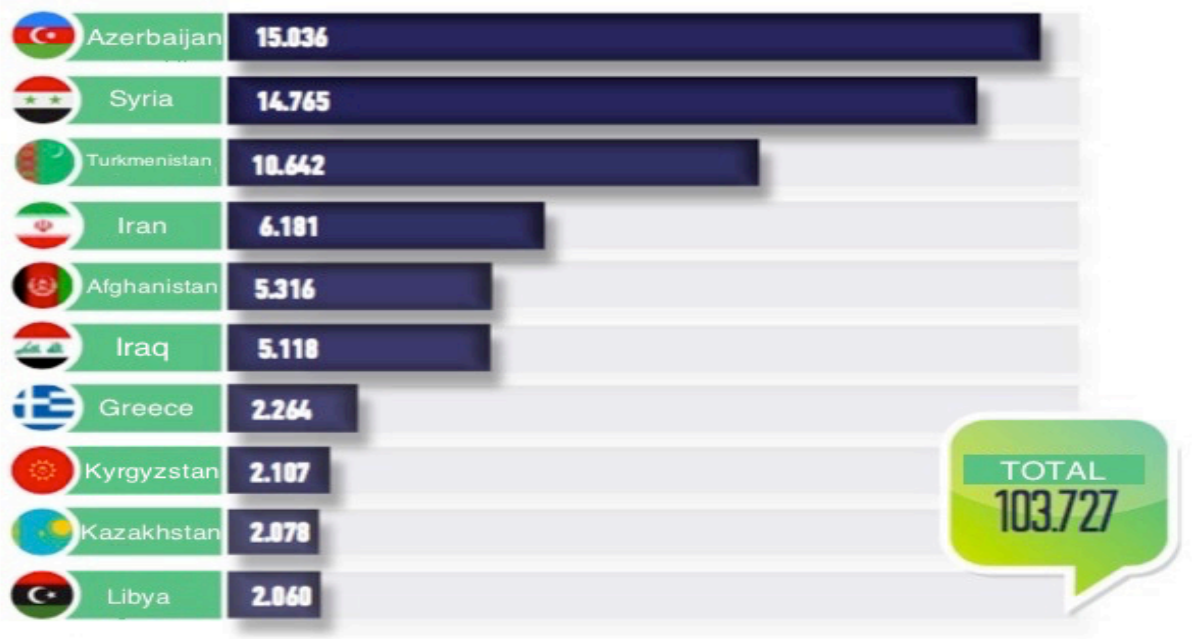

Figure 1. Number of international students by countries in Turkish higher education 
Regarding the mobility of international students, it can also be said that the world witnesses a higher rate of international student mobility. Previous research also shows that an increasing number of students preferred to study at a university abroad [8, 17]. As Van Damme [21] stated 'the term 'internationalization' refers to the activities of higher education institutions, often supported or framed by multilateral agreements or programs, to expand their reach over national borders" (p. 417).

Previous research indicates that there are different views in relation to academic performances of international students. For instance, Robertson et al., [16] carried out a research about learning environment and perceptions of international students in Australia and found out that attending less to the classes is the main contributing factor to language weaknesses. In Robertson's study [16], students also expressed similar views about the language proficiency problem. In another study carried out by $\mathrm{Li}$ et al. [10], academic and cultural factors on academic performance of international students were examined and the researchers found out that proficiency in English and social communication were regarded as the significant predictors of academic performance. Furthermore, Karadağ [9] carried out a study about the Syrian students in the context of Turkish higher education and found out that the university in which the study was conducted could not organize social events for international students. However, the university academics were able to provide support for Turkish courses and accommodation. In relation to usage of Turkish language, Özoğlu, Gür and Coşkun [13] found out that prominent problem which international students faced is related to learning the language.

As this hot topic is on the agenda of many researchers, academics and educational policymakers, a number of research have been carried out in order to have a deeper understanding and interpretation regarding international students' needs, adaptation and pedagogical problems. Research cited about international students mainly includes issues such as internationalization, academic performance, cultural factors, adaptation factors, needs analysis and the integration of international students in higher education [2, $5,7,10]$. Of all the issues mentioned, international students' academic achievement has gained greater attention in the literature. Several studies have shown that academic achievement plays a key role in predicting students' learning outcomes $[11,12]$. In relation to academic achievement, learning skills and learning habits are shown to affect the learning process of the students [1]. It is a fact that there are wide varieties of factors affecting students' academic performance such as social, cultural, educational and psychological $[6,15]$.

It is clear that Turkey has not had much experience concerning international students' teaching and learning cycles. Yet, Higher Education Council, Ministry of National Education, institutions connected directly to presidency and non-governmental organizations in Turkey have recently started new projects and adopted new educational policies for the benefit of international students. The courses on teaching Turkish as a foreign language, orientation programs regarding adaptation issues and international conferences are among the recent attempts initiated. The study about the expectations of Syrian students carried out by Seydi [19] found out that their expectations are directly based on the regulations taken by Turkish government in line with Higher Education Council and Ministry of National Education. In this context, in 2013, "Teaching Training Seminar" organized by Ministry of National Education, UNICEF and Disaster and Emergency Management Authority was organized for the volunteer teachers who teach in Syrian refugee camps for the purpose of solving the educational problems and getting them to have psychological comfort. Another initiative example taken by Higher Education Council was related to the right given to Syrian student as special student in seven universities near the border of Syria in the academic year 2012-2013. The Council also embarked on private courses for the Syrian students. Furthermore, Turkish language courses were also administered in the Syrian camps organized by non-governmental organizations in Turkey.

This study is an attempt to explain the conditions that affect international students' achievement and pedagogical progress in a Turkish public university through students' and academics' views and classroom observations. The rationale behind conducting this study in the target university is to better understand the underlying reasons why the international students' academic achievement levels are below the average (e.g. overall GPA score of international students is 1,41). In the current study, the term 'international students' is defined as students who mainly come from Syria and Azerbaijan. Taking the high proportion of Syrian students into consideration, a particular emphasis is given to this group.

\subsection{Research Questions}

The research questions of the study to have understanding about the views that affect international students' academic achievement and pedagogical progress were ere as follows:

1. What are the international students' views regarding the conditions for their academic achievement and progress in a Turkish university?

2. What are the academics' views regarding the conditions for academic achievement and progress of international students in a Turkish university?

\section{Method}

This study adopts qualitative research methodology to collect data based on open-ended questions and classroom 
observations. Data were collected from 15 students $(10$ male and 5 female) and 8 academics (one of them is the researcher) from different disciplines in the target university. One of the stages carried out in 2017 was a statistical analysis of the international students' overall GPA scores. The data concerning GPA scores by country and grade were gathered from the Registrar's Office in the target university. The data provided a baseline for underlying the purposes of the study.

A survey containing six open-ended questions were used to learn students' and academics' views regarding the topic. The open-ended questions were prepared in Turkish language in order to obtain their views more clearly and piloted with a smaller group of international students before the actual study. Some modifications were made in the questions following the pilot study. In addition, the opinion of an expert in qualitative research design was elicited on the structure of the survey. For the purpose of providing validity procedure, the instruments were triangulated, which is a systematic process of sorting through the data to find common themes or categories by eliminating overlapping areas [5].

\subsection{Research Context}

The target university in which the study was conducted is located in the Mediterranean region of Turkey, which is near Syria. Thus, there are many international students from Syria. In accordance with the legislation undertaken by Turkish government, Syrian refugee students have the chance to enroll and continue their education, if they want and if they have Turkish language proficiency. This state university offers Turkish language courses at both graduate and postgraduate levels and it has almost 14.000 students. It has six faculties, three institutes, five vocational schools and three schools.

\subsection{Participants}

In the study, from among the international students who volunteered, 15 students, (10 male and 5 female) and 8 academics (one of them is the researcher) from different disciplines were chosen as participants. The participants were informed about the voluntary nature of the study. The participants study in the departments of social and applied sciences in different grades. The academics are also from different departments. Out of 15 international students participated in the study, 7 participants are from Syria and they are in the first, second and third grade level students. 5 participants are from Azerbaijan and they are in second, third and fourth grade. 2 participants are from Turkmenistan, 1 from Afghanistan and they are in the first grade. There are 247 international students in the target university mostly from Syria and Azerbaijan in the setting of the study. The following table shows the distribution of the number of international students by countries at the target university.

Table 1. Distribution of the international students by the countries at the target university

\begin{tabular}{|c|c|c|c|c|}
\hline & Frequency & Percent & Valid Percent & Cumulative Percent \\
\hline Afghanistan & 3 & 1,2 & 1,2 & 39,3 \\
\hline Azerbaijan & 62 & 25,1 & 25,1 & 25,1 \\
\hline Egypt & 1 &, 4 &, 4 & 37,7 \\
\hline Kenya & 1 &, 4 &, 4 & 39,7 \\
\hline Kirghizstan & 1 &, 4 &, 4 & 37,2 \\
\hline Palestine & 1 &, 4 &, 4 & 40,1 \\
\hline Syria & 148 & 59,9 & 59,9 & 100,0 \\
\hline Turkey & 10 & 4,0 & 4,0 & 36,8 \\
\hline Turkmenistan & 19 & 7,7 & 7,7 & 32,8 \\
\hline Zambia & 1 &, 4 &, 4 & 38,1 \\
\hline TOTAL & 247 & 100,0 & 100,0 & \\
\hline
\end{tabular}

As it is clear in Table 1, most students in the target university are from Syria and Azerbaijan. The number of international students in this university from different departments and grades is 247 in 2017, 148 from Syria and 62 from Azerbaijan. The following figures show the distribution of the international students by grades at the target university.

Table 2. Distribution of participants by grades at the target university

\begin{tabular}{|c|c|c|c|c|}
\hline Grade & Frequency & Percent & Valid Percent & Cumulative Percent \\
\hline First Grade & 51 & 20,6 & 20,6 & 20,6 \\
\hline Second Grade & 88 & 35,6 & 35,6 & 56,3 \\
\hline Third Grade & 42 & 17,0 & 17,0 & 73,3 \\
\hline Fourth Grade & 66 & 26,7 & 26,7 & 100,0 \\
\hline Total & 247 & 100,0 & 100,0 & \\
\hline
\end{tabular}

\subsection{Procedures}

The qualitative data were collected using a survey containing six open-ended questions applied to the students and academics and classroom observations were conducted over time. Besides, second-wave interviews with some of the students and academics were held in order to have a broader perspective regarding the topic. The researcher used highly structured observation which means sitting passively in the classroom and attended the classes knowing what to do and took some notes about the academics' teaching methods and approach to the students [14]. Before attending the classes, the researcher talked the lecturers and gave detailed information about the purpose and procedure of the study. The researcher himself also taught in some of the classes which involves international students and attended four courses to observe international students and classroom environment. In these classrooms, the researcher took some notes regarding students' motivation levels, attendance and participation. Besides the 
observational facts about those students, the researcher also monitored the academics' and their classmates' approaches to these students.

The collected data were analyzed by conducting thematic analysis. An independent qualitative descriptive research method, thematic analysis is defined as a method for identifying, analyzing and reporting patterns (themes) within data [3]. In order to analyze data, the researcher firstly tried to familiarize the data by reading, rereading, listening the recordings, and then took notes. Secondly, the researcher generated codes and searched for main themes.
Thirdly, the researcher provided the conclusion and discussion about the analysis.

\section{Results}

\subsection{Descriptive Results about GPA Scores}

The GPA scores were analyzed according to the countries participating in the study (Table 3 ).

Table 3. GPA scores by the countries at the target university

\begin{tabular}{|c|c|c|c|c|c|c|c|c|}
\hline & \multirow{2}{*}{$\mathrm{N}$} & \multirow{2}{*}{ Mean } & \multirow{2}{*}{ Std. Deviation } & \multirow{2}{*}{ Std. Error } & \multicolumn{2}{|c|}{ 95\% Confidence Interval for Mean } & \multirow{2}{*}{ Minimum } & \multirow{2}{*}{ Maximum } \\
\hline & & & & & Lower Bound & Upper Bound & & \\
\hline Afghanistan & 3 & 60 & 1,04 & ,6000 & $-1,982$ & 3,182 &, 00 & 1,80 \\
\hline Azerbaijan & 62 & 1,02 & ,74 & 0935 & 831 & 1,205 &, 00 & 2,94 \\
\hline Egypt & 1 & 1,56 & . & . & . & . & 1,56 & 1,56 \\
\hline Kenya & 1 & 2,91 & . & . & . & . & 2,91 & 2,91 \\
\hline Kyrgyzstan & 1 &, 10 & . & . & . & . &, 10 &, 10 \\
\hline Palestine & 1 & 2,29 & . & . & . & . & 2,29 & 2,29 \\
\hline Syria & 148 & 1,62 & 1,12 & ,0924 & 1,442 & 1,807 & ,00 & 3,76 \\
\hline Turkey & 10 & 1,54 & ,97 & ,3074 &, 848 & 2,238 &, 00 & 3,06 \\
\hline Turkmenistan & 19 & ,91 &, 82 & , 1886 & ,514 & 1,306 &, 00 & 2,37 \\
\hline Zambia & 1 & 3,38 & . & . & . & . & 3,38 & 3,38 \\
\hline TOTAL & 247 & 1,41 & 1,05 &, 0671 & 1,278 & 1,543 &, 00 & 3,76 \\
\hline
\end{tabular}

Looking at the table, it is clear that the GPA average of all countries is 1.41 . When countries ranked starting from the highest average GPA, the result is as follows: Zambia $(\bar{X}=3.38)$, Kenya $(\bar{X}=2.91)$, Palestine $(\bar{X}=2.29)$, Syria $(\bar{X}$ =1.62), Egypt $(\bar{X}=1,56)$, Turkey $(\bar{X}=1,54)$, Azerbaijan $(\bar{X}=1,02)$, Turkmenistan $(\bar{X}=0,91)$, Afghanistan $(\bar{X}=$ $0,60)$ and $\operatorname{Kyrgyzstan}(\overline{\mathrm{X}}=0,10)$.

The GPA scores according to the grades of participants are given in Table 4 .

Table 4. GPA scores by the participants' grades at the target university

\begin{tabular}{|c|c|c|c|c|c|c|c|c|}
\hline \multirow{2}{*}{ Grades } & \multirow{2}{*}{$\mathrm{N}$} & \multirow{2}{*}{ Mean } & \multirow{2}{*}{ Std. Deviation } & \multirow{2}{*}{ Std. Error } & \multicolumn{2}{|c|}{$95 \%$ Confidence Interval for Mean } & \multirow{2}{*}{ Minimum } & \multirow{2}{*}{ Maximum } \\
\cline { 6 - 9 } & & & & & Lower Bound & Upper Bound & & \\
\hline First Grade & 51 & 1,74 & 1,17 &, 164 & 1,408 & 2,067 &, 00 & 3,58 \\
\hline Second Grade & 88 & 1,40 & 1,13 &, 121 & 1,161 & 1,641 &, 00 & 3,76 \\
\hline Third Grade & 42 & 1,00 &, 91 &, 140 &, 721 & 1,287 &, 00 & 3,04 \\
\hline Fourth Grade & 66 & 1,43 &, 85 &, 105 & 1,219 & 1,638 &, 00 & 3,47 \\
\hline Total & 247 & 1,41 & 1,06 &, 067 & 1,278 & 1,543 &, 00 & 3,76 \\
\hline
\end{tabular}

When Table 4 is examined, it is clear that the highest GPA average is 1.74 and the first grade students have the lowest GPA scores which is 0.85 . 


\subsection{International Students' and Academics' Views}

In relation to students' and academics' views, themes identified:

- Low level of Turkish proficiency, especially in writing and speaking

- Culture shock based on adaptation and adjustment problems

- Economic problems

The following paragraph gives some examples of students' remarks regarding main themes. One of the participants stated that:

"I want to follow the lectures but my Turkish level is not enough. The exams are especially difficult for me and I can't reflect what I think in written during the exams".

Another participant said that:

"Turkish is a very difficult language to learn for me as there are striking differences between Turkish and Arabic languages. I'm learning Turkish at a very slow pace".

Some of the participants from Syria expressed their views on culture shock:

"When I first came to Turkey, I was shocked by people's lifestyles and cultural norms in Turkey are different from my native country and this affected my academic achievement and social relationships.

"As it is known, we escaped from war started in 2011, we left our lands and sheltered in Turkey. Turkey gave us opportunity to study in the universities, however it was not an easy step for us to adapt."

One of the participants stated that:

"Turkey is a very great country compared to my own country. I had economic problems while studying. My family couldn't afford me to meet my basic requirements, so I needed to find a part-time job, but it is really hard for me to study and work at the same time".

Another participant made remarks that:

"I don't have enough money and I can't find anybody to support me financially during my education, which affected my academic progress badly".

Academics' views results are also compatible with the students' views especially for Turkish proficiency level. Some of the participants stated that:

"They need intensive Turkish courses before taking departmental courses. There seems to be a problem with Turkish proficiency test they take, I don't believe that this exam measures their Turkish level correctly".
"I have trouble even in marking the exam papers of international students. During the class, they rarely speak, comment or ask a question. Besides, they generally don't bring their learning materials to the class".

Another academic expressed such a view:

"They are physically in the classroom, but it seems that their minds are somewhere else. I think they suffer from homesickness and they have some financial problems, which makes it very difficult for them to adapt a new culture and learning environment".

As it is clear from the students' and academics' views, main themes are related to Turkish proficiency, cultural shock and economic problems. As it is mentioned before, the study was carried out in the university in which Turkish courses are not available once the study was conducted. Thus, when international students get the right to study, they should have first Turkish proficiency certificate, which is important for international students while choosing the university. Looking at the number of students who enrolled at the target university, it is clear that the number of students is low.

Students claimed that their Turkish proficiency level is not good enough to continue their education especially in the first grade. They also stated that they can understand the daily language; however, they have some difficulties regarding the topics in the classrooms. They also faced challenges in writing in the exams. But, as they adapt to the Turkish higher education system and their Turkish proficiency level has increased gradually, their problems were diminished, but not disappeared. However, educational background problem appears in this cycle. Similar views were also stated by the academics.

As for the academics' views, it can be said that it is hard for them to ensure the balance in the classroom. On one side, there are a few low-level students and on the other side, there are some Turkish students striving to learn much more. One of the academics stated that one Syrian refugee student had low level, and he couldn't find a proper teaching method, furthermore he stated that the student had the chance to continue their education regardless of students' low level. The academics also claimed that they would like to help these international students; however, there is a lack of institutional and organizational support.

\subsection{Classroom Observations}

In relation to the findings related to the classroom observations, it can be said that most of the participants have not sufficient stimuli to learn new subjects or improve themselves and they value success in the exams and getting a degree from the university, which can stem mainly from their Turkish language level, their background and economic, social and cultural problems. In the classroom 
environment, they do not generally involve in the course and do not share opinions. The students listen to the course content solely and do not take almost any notes. Moreover, they do not always bring any materials, books and notebooks etc. This shows that they appear in the classes but most of them do not pay attention to the courses properly.

As for the academics' attitudes towards these international students in the classes, it can be said that the general attitude is considerate and thoughtful, but it is necessary to mention the fact that they would like to help them provided that the students show interest in the classes. The academics tried to be clear and concise while teaching in the class, however, those students were not proficient enough to understand the course content properly. Classroom observations also show that the class population is normally $60-70$ students with native and international students together, 5-6 of whom are international students in general. Thus, academics teach courses for all of the students, that is, they do not have any chance to give special lectures to the international students.

\section{Discussion and Conclusions}

This study was designed to investigate the conditions that affect international students' academic achievement and pedagogical progress through students' and academics' views together with classroom observations. Participants in this study were selected randomly and informed about the purpose and nature of the study in advance. They were mostly Syrian and Azerbaijani students studying in different disciplines in the target university. There is a striking characteristic feature here that distinguishes Syrian students from the others. The researcher got the idea that Syrian refugee students were affected by the war in 2011 and most of them escaped from the war and sought shelter in Turkey. Thus, it can be said that surviving in this new culture and place is the primary goal of the international students but not the educational progress.

This qualitative research aims to explain the conditions that affect international students' academic progress and achievement based on students' and academics' views and classroom observations. As Higher Education Council (HEC) in Turkey puts forward that globalization can be seen as one of the leading factors that affect the internalization due to the demographic and economic reasons [23]. Trice [20] found out that compared to domestic students, international students encountered certain obstacles such as academic, individual and social ones. In line with the previous literature, this research also revealed that not only students but also academics expressed that they had some certain challenges in the learning and teaching process.

The results of the analysis provide three main insights regarding international students in higher education. First, the students' GPA scores' average is 1,41 for all the grades, which is low and this shows the linear relationship with the remarks of these students. Second, students' views indicate that although they are satisfied with the conditions and opportunities they are provided with, the level of academic achievement is very low. Academics stated that they would like to help international students in their academic progress yet, students' educational background and language proficiency levels are not good enough to keep up with the learning process. Furthermore, according to Azerbaijani students, Turkey is one of the best places to pursue their education and thereby enabling to foster and improve themselves in all senses. A possible explanation of these views might be that, in the current context, Turkey offers best educational practices and teaching for their future compared to their home country. This fact is almost valid for all of the students who participated in the study. However, it should be stated here that most Syrian refugee students do not feel comfortable and they miss their homeland, so learning is not their first target which stems from factors mainly related to war in 2011 in Syria. Third, teaching and learning practices applied in Turkish higher education for international students should be more disciplined and systematic when thinking that the number of students is increasing gradually per year. Taking the findings into account, it can also be said that the communication problems gradually disappear for the fourth grade students in particular, yet understanding the course content still remains a problematic area.

According to Ryan and Viete [18], there are several important principles in order to provide successful learning for international students in an English-speaking environment, which include 'feelings of belonging; being valued as a person with knowledge; and being able to communicate effectively, creatively, and with confidence' (p. 309). This can be true for all of the institutions and international students regardless of the medium of instruction. In relation to this, Chen [4] published a paper about the international students and found out that academics should be more thoughtful and mindful about the language use in the classroom environment. In this context, it is important to note that making internationalization strong and practical in higher education in Turkey not only contributes to the regional and global position of our country but also increase the quality of teaching and learning environment in the universities [23].

Furthermore, it can be implicated that the success of adaptability can be improved by the availability of institutional and organizational support in higher education. Like many countries in the world, Turkey is also searching for solutions to improve the standards of international students ranging from pedagogical process, teaching methods to acculturation and social activities, thus it is hoped that this study may contribute to this field and provide assistance and support for further research. 
Taking the limitations of the study into consideration, this study was limited to 15 international students and 8 academics from different discipline and grades. Moreover, the scope of the study was restricted to qualitative data collected from open-ended questions and classroom observations. Thus, future research may investigate the topic by using mixed method research design with more participants.

\section{REFERENCES}

[1] Abbott-Chapman, J., Hughes, P., \& Wyld, C. (1992). Monitoring student progress: A framework for improving student performance and reducing attrition in higher education. Hobart, Tasmania: National Clearinghouse for Youth Studies.

[2] Andrade, M. S. (2006). International students in English-speaking universities: Adjustment factors. Journal of Research in International education, 5(2), 131-154.

[3] Braun, V., \& Clarke, V. (2006). Using thematic analysis in psychology. Qualitative research in psychology, 3(2), 77-101.

[4] Chen, L. (2006). Internationalizing Canadian graduate education: East Asian international students' perspectives. Scarborough, Ontario, Canada: University of Toronto, Department of Management.

[5] Creswell, J. W. \& Miller, D. L. (2000). Determining validity in qualitative inquiry. Theory into Practice, 39(3), 124-131.

[6] Gerdes, H., \& Mallinckrodt, B. (1994). Emotional, social, and academic adjustment of college students: A longitudinal study of retention. Journal of Counselling and Development, 72, 281-288.

[7] Guo, S., \& Chase, M. (2011). Internationalization of higher education: Integrating international students into Canadian academic environment. Teaching in Higher Education, 16(3), 305-318.

[8] Healey, N. (2008). Is higher education 'internationalizing'? Higher Education, 55(3), 333-355.

[9] Karadağ, N. (2016). A Research on the Syrian Students Educated in Turkey in the Context of Internationalization in Higher Education", Turkish Studies, ISSN: 1308-2140, Volume 11/19, doi number: http://dx.doi.org/10.7827/Turki shStudies.11155, p. 477-490.

[10] Li, G., Chen, W., \& Duanmu, J. L. (2010). Determinants of international students' academic performance: A comparison between Chinese and other international students. Journal of Studies in International Education, 14(4), 389-405.
[11] McKenzie, K., Gow, K., \& Schweitzer, R. (2004). Exploring first - year academic achievement through structural equation modelling. Higher Education Research \& Development, 23(1), 95-112.

[12] McKenzie, K., \& Schweitzer, R. (2001). Who succeeds at university? Factors predicting academic performance in first year Australian university students. Higher Education Research and Development, 20, 21-33.

[13] Özoğlu, M., Gür, B., \& Coşkun, İ. (2012). Küresel eğilimler 1şı̆̆ında Türkiye'de uluslararası öğrenciler (International students in Turkey in the light of global tendencies). Siyaset, Ekonomi ve Toplum Araştırmaları Vakfi (Foundation for political, economic and social research), Ankara.

[14] Patton, M. Q. (1990). Qualitative Evaluation and Research Methods. London: Sage.

[15] Pokay, P., \& Blumenfeld, P. (1990). Predicting achievement early and late in the semester: The role of motivation and use of learning strategies. Journal of Educational Psychology, 82, 41-50.

[16] Robertson, M., Line, M., Jones, S. \& Thomas, S. (2000) International students, learning environments and perceptions: A case study using the Delphi technique. Higher Education Research \& Development, 19(1): 89101.

[17] Russell, J., Rosenthal, D., \& Thomson, G. (2010). The international student experience: Three styles of adaptation. Higher Education, 60(2), 235-249.

[18] Ryan, J., \& Viete, R. 2009. Respectful interactions: Learning with international students in English-speaking academy. Teaching in Higher Education, 14(3), 303-314.

[19] Seydi, A. R. (2013). Türkiye'deki Suriyeli akademisyen ve eğitimcilerin görüşlerine göre Suriye'deki çatışmaların Suriyelilerin eğitim sürecine yansımaları (The reflections of conflicts in Syria on the educational process of Syrians from the perspectives of Syrian academicians and educators in Turkey). Süleyman Demirel University Faculty of Arts and Sciences Journal of Social Sciences, (30), 217-241.

[20] Trice, A. (2003). Faculty perceptions of graduate international students: The benefits and challenges. Journal of Studies in International Education. 7(4): 379-403.

[21] Van Damme, D. (2001). Quality issues in the internationalization of higher education. Higher Education, 41(4), 415-441.

[22] Turkish Migration Report. (2016). The Republic of Turkey, Ministry of Interior, Directorate General of Migration Management. http://www.goc.gov.tr/files/files/2016 goc raporu_.pdf

[23] Higher Education Council, HEC. (2014). Büyüme, kalite, uluslararasılaşma: Türkiye Yükseköğretimi İçin Bir Yol Haritas1 (Growth, quality, internationalization: A road map for Turkish higher education). 